\title{
Portable Solar Charger with Controlled Charging Current for Mobile Phone Devices
}

\author{
Hussain A. Attia*, Beza Negash Getu, Hasan Ghadban, Ahmed K. Abu Mustafa \\ Electronics and Communications Engineering Department, American University of Ras Al Khaimah, UAE
}

\begin{abstract}
In this paper, we design, construct as well as test and analyze an electronic circuit that can be used as a solar portable charger for mobile phone devices using the solar energy as a source of electric power. A suitable small size solar cell panel is selected that is easy to carry to any locations farther from city electric grids. The alternative use of the solar energy as power source is helpful in outdoor emergency situations and avoids the traditional way of waiting beside an electrical sockets or outlets for charging. We suggest here a special electronic design and construction with an important merit related to controlling battery charging currents. Software verification and simulations, laboratory experiments on the circuit, practical testing to the charging capabilities; all these are discussed in this paper.
\end{abstract}

Keywords: Solar power; photovoltaic; solar panel; mobile phone; portable charger; mobile battery; charging current

\section{Introduction}

Recently various types of chargers that utilize the solar energy as a source of power are emerging. They might have variations in their design, construction, time and cost of work and the type of components used in the prototypes but their overall purpose is charging cell phone or other wireless devices [1]-[5]. However, they have differences in their merits that motivate us to present a new design with special merit related to controlling the battery charging current. The charging circuits are used to charge Lead Acid, NiCd or other types of batteries. The circuits harvest solar energy to charge rechargeable batteries for various applications. The electronic circuits often use solar panels consisting of few or several solar cells, standard voltage regulator integrated circuits (IC) chips, transistors, Zener diodes, diodes and resistors all of them used to regulate the output voltage and charging currents. Through our research, we have made special attention to the design specifications for the circuits designed previously. The first design in [2] was made from an IC and it completely depends on Maximum Power Point Tracking (MPPT) algorithm to deliver the charging power of a mobile battery. Other design in [3] represents a solar charger for battery $3.7 \mathrm{~V} @ 2000 \mathrm{mAh}$, the design and construction again depends on integrated circuits as a main part of the controlling circuit. The circuit diagram for a project presented by Colin Mitchell in 2005 [4] showed a solar charger. The problem faced by this circuit is due to the output levels (the output current is 15 $\mathrm{mA}$ ) whereas the necessary minimum current for charging battery is often $75 \mathrm{~mA}$ although it has an output voltage of 5 Volts. Other design in [5] is a shunt-mode charge controlled solar charger. This circuit has been used to prevent the battery from overcharging and this procedure is done by interrupting the flow of current by the charge controller when the battery reaches full voltage. Due to the high voltage output which is 18 Volts and the greater number of solar cells ( 36 cells), it may be difficult to adopt this design for a mobile phone charger.

Here, we investigate a complete design and construction for an electronic circuit that will be used for charging mobile devices. This paper starts with description of the original designed circuit and it's components in Section II. In Section III, a complete analysis to the presented design will be given. The experimental work and the practical testing results to the constructed circuit will be explained in Section IV. The paper concludes with the explanation of the important merits of our design in Section V.

\footnotetext{
*Corresponding author. E-mail: hattia@aurak.ae

(C) 2014 International Association for Sharing Knowledge and Sustainability

DOI: $10.5383 /$ ijtee.07.01.003
} 


\section{Circuit Diagram for the Portable Solar Power Charger}

The complete design of the proposed circuit is shown in Fig. 1. It was designed and tested using simulation software called National Instruments (NI) MultiSim, which is currently one of the leading software programs for electronic circuits design and simulations [6]. It includes an internal huge library and database of so many electrical and electronic components with an ability to test and measure around any test points included in the designed circuit.

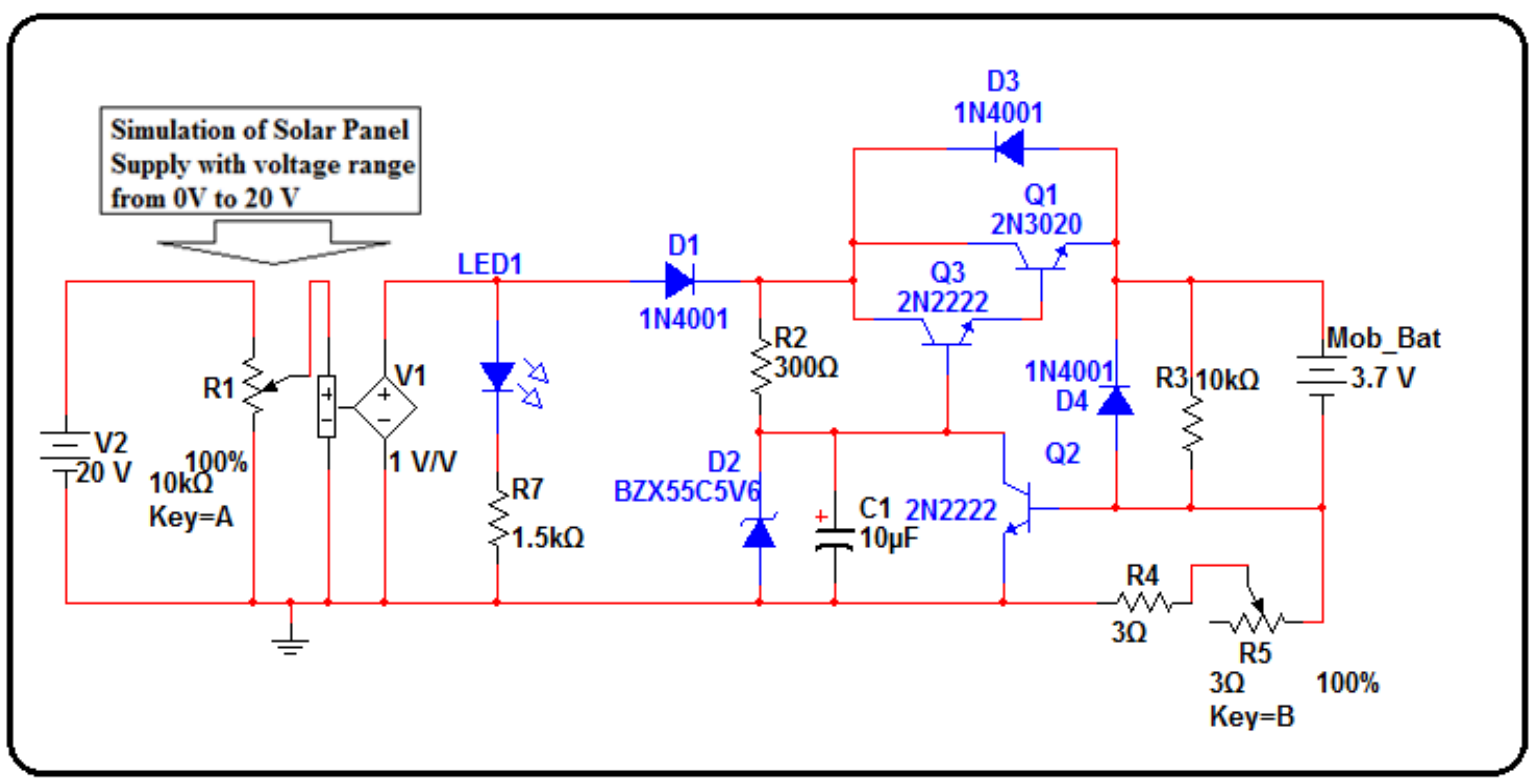

Fig. 1: The proposed electronic circuit of portable solar charger

The proposed circuit includes the following components: Solar Panel (with specifications: $5 \mathrm{~W}, 17.6 \mathrm{~V}, 0.28 \mathrm{~A}$ ), Darlington NPN transistor, NPN transistor type 2N2222, Zener Diode (with break down voltage $\mathrm{V}_{\mathrm{z}}=5.6 \mathrm{~V}$ ), Diodes (3 1N4001 types), LED, potentiometer ( $3 \Omega / 0.25$ $\mathrm{W})$, Capacitor $(10 \mu \mathrm{F})$, Resistors $(0.25 \mathrm{~W})$. The solar panel, which is the main component of the design, is a collection of individual silicon type photovoltaic (PV) cells that generate electricity from sunlight. The photons (light particles) produce an electrical current as they strike the surface of the thin silicon wafers [7], [8], [9]. As shown in the presented design, the controlling functions for charging voltage and current were made using simple electronic components and the details of the functions will be explained in the next sections.

\section{Circuit Analysis and Simulation}

The solar panel will be the DC voltage source or supply for the electronic circuit shown in Fig.1 with the range of voltage from minimum $0 \mathrm{~V}$ at dark to maximum voltage reaching up to approximately $20 \mathrm{~V}$ during high intensity sunlight absorption.

The first light emitting diode (LED1) in the circuit is used as visual indication for the activity of solar panel at any instantaneous time. R7 is a series resistor connected with LED to limit the current that passes through the diode. The value of $\mathrm{R} 7$ is $1.5 \mathrm{~K} \Omega$ and this is calculated to allow rated current of the LED $(12 \mathrm{~mA})$ at maximum solar panel voltage $(20 \mathrm{~V})$. The diode D1 is used to guide the current from the power supply (solar panel) to the remaining part of the electronic circuit and prevent any reverse current from the circuit to the solar panel.

The values of the other three components connected together (after the diode) are: Resistor, $\mathrm{R} 2=300 \Omega / 1 \mathrm{~W}$, Zener Diode D2 with $\mathrm{Vz}=5.6 \mathrm{~V} / 0.5 \mathrm{~W}$, Capacitor $\mathrm{C} 1=$ $10 \mu \mathrm{F} / 25 \mathrm{~V}$. The Zener diode is connected in reverse biasing to have regulated voltage across the diode fixed at $5.6 \mathrm{~V}$ when the output of the solar panel is more than Zener diode breakdown voltage. The value of the required power of the zener diode can be calculated at maximum input supply voltage and maximum current that passes through R2 by using the following relation:

$\operatorname{Imax}=(\mathrm{Vmax}-\mathrm{Vz}) / \mathrm{R} 2$

The value of $\operatorname{Imax}=(20-5.6) / 300=48 \mathrm{~mA}$, so the required power for the zener diode is equal to

$\mathrm{Pz}=\mathrm{Vz} * \mathrm{Iz}=5.6 *(20-5.6) / 300=0.269 \mathrm{~W}$

The selected Zener is rated $5.6 \mathrm{~V} / 0.5 \mathrm{~W}$, and by same principle the actual power dissipated in $\mathrm{R} 2$ is equal to:

$\mathrm{P}(\mathrm{R} 2)=\left(\operatorname{Imax}^{\wedge} 2\right) * \mathrm{R} 2=\left(0.048^{\wedge} 2\right) * 300=0.691 \mathrm{~W}$ 
For safety reasons, the practical selected value of $\mathrm{R} 2=$ $300 \Omega / 1 \mathrm{~W}$. The reason of using $\mathrm{C} 1=10 \mu \mathrm{F} / 25 \mathrm{~V}$ in parallel with zener diode is to improve the stability and transient behavior of the voltages produced by the solar panel.

The next part is the Darlington connection. This Darlington connection leads to an increase current gain $(\beta=\beta 1 * \beta 2)$ so that the emitter current of Q1 (2N3020) will guarantee to deliver enough mobile battery charging current [10] with the output charging voltage equal to the zener voltage minus the summation of the two baseemitter forward voltages of the Darlington connection: Q3 (2N2222/40V, 0.8A, 0.5 W), and Q1 (2N3020/80 V, $1 \mathrm{~A}, 5 \mathrm{~W})$. The high power transistor $2 \mathrm{~N} 3020$ is selected since it has a good limit of dissipated power compared with the actual required level at the maximum solar panel voltage. The actual power that is dissipated at Q1 is calculated from maximum Vce and maximum Ic current and it is calculated as follows:

Maximum Vce $=$ Maximum Solar panel Voltage Mobile Battery voltage $=20-3.7=16.3 \mathrm{~V}$

Maximum Ic $=$ Maximum charging current $=200 \mathrm{~mA}$

So, Maximum Power needed $=$ Vce $(\operatorname{Max}) * \operatorname{Ic}(\operatorname{Max})=$ $16.3 * 0.2=3.26 \mathrm{~W}$

D3 (1N4001) and D4 (1N4001) are used for safety of the Darlington connection and the remaining parts of the electronic circuit from any unnecessary spark voltages that may be produced during switching and between connection and disconnection of the mobile battery.

The connection of Q2 (2N2222) with R4 (3 $\Omega$ ), and R5 $($ Pot $=3 \Omega)$ is one of the main ideas of the proposed electronic circuit. Q2 is used to make control of the battery charging current and the desired limit is determined by the proper choice of the total resistance $\mathrm{R} 4+\mathrm{R} 5$. Since R5 is the potentiometer resistor, there is a possibility to change it from $0 \Omega$ or short circuit to maximum value equal to $3 \Omega$, so that the summation of $\mathrm{R} 4+\mathrm{R} 5$ will be varied from $3 \Omega$ (minimum) to $6 \Omega$ (maximum). This is used to control the charging current of the mobile battery and then transduce the current to voltage across $\mathrm{R} 4+\mathrm{R} 5$ that will be used to drive the base of the transistor Q2. When the transistor Q2 is switched on, its base-emitter voltage is close to $700 \mathrm{mV}$, and it determines the battery charging current as follows:

- $\quad \mathrm{I}$ (charging) $=($ the voltage across R4+R5 $) /($ the value of resistance R4+R5 )

- $\quad$ I $($ Max. Charging $)=0.7 /($ Min. of R4+R5) $=$ $0.7 / 3=233 \mathrm{~mA}$

- $\quad$ I $($ Mid. Charging $)=0.7 /($ Mid. of R4+R5 $)=0.7$ $/ 4.5=155 \mathrm{~mA}$

- $\quad \mathrm{I}($ Min. Charging $)=0.7 /($ Max. of R4+R5 $)=$ $0.7 / 6=116 \mathrm{~mA}$

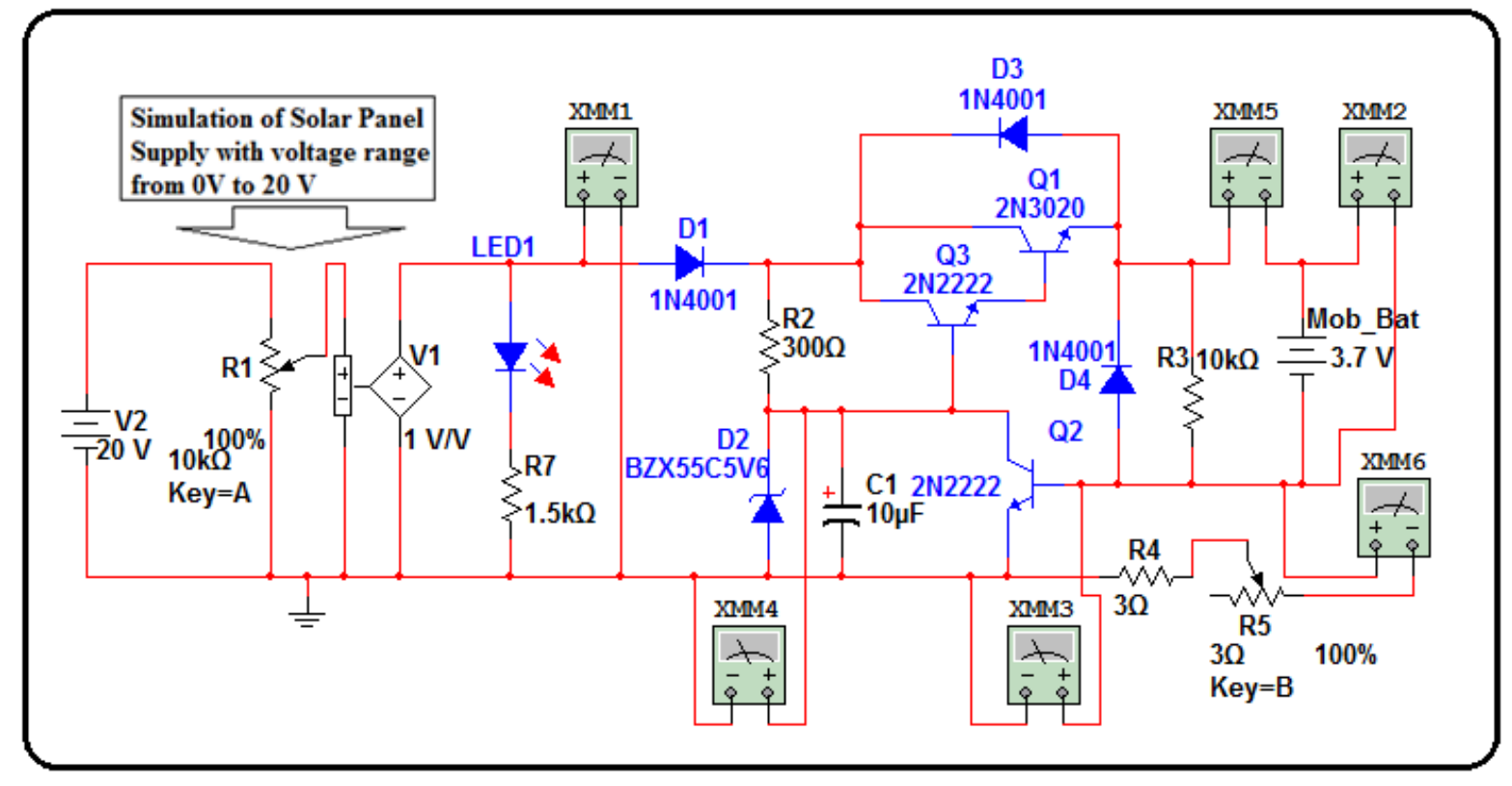

Fig. 2. The circuit of portable solar charger with voltage and current measurement probes

Fig.2 shows the simulation set up and all the measurement devices: voltmeters and ammeters that are used to prove the parameter values of our analysis and the objectives of the proposed electronic design. The simulated measurement results of all the six meters are shown in Table 1 and Table 2 for the three values of total shunt resistor (R4+R5): these values are $6 \Omega, 4.5 \Omega$ and $3 \Omega$ for minimum, medium and maximum charging currents respectively.
Table 1 compares the zener diode voltages when the simulated solar panel voltage is varied for the three charging current cases (Min, Mid, Max). Table 2 shows the three charging currents for different values of simulated solar panel voltages.

Table 1. Comparison table for Zener Voltages at the three levels of charging currents 


\begin{tabular}{|c|c|c|c|}
\hline \multicolumn{4}{|c|}{$\begin{array}{l}\text { Simulation Data of Zener voltages at the three levels of } \\
\text { charging current and different values of Solar Panel Voltages }\end{array}$} \\
\hline $\begin{array}{l}\text { Solar } \\
\text { Panel } \\
\text { Vin } \\
\text { (V) }\end{array}$ & $\begin{array}{l}\text { Zener Voltage } \\
\text { Vz }(\mathrm{V}) \text { at I } \\
\text { charge(Min), } \\
\mathrm{R} 4+\mathrm{R} 5=\text { Rshunt } \\
=6 \Omega\end{array}$ & $\begin{array}{l}\text { Zener Voltage } \\
\text { Vz (V) at I } \\
\text { charge(Mid), } \\
\text { Rshunt }=4.5 \Omega\end{array}$ & $\begin{array}{l}\text { Zener Voltage } \\
\text { Vz }(\mathrm{V}) \text { at I } \\
\text { charge(Max), } \\
\text { Rshunt }=3 \Omega\end{array}$ \\
\hline 6 & 5.271 & 5.261 & 5.246 \\
\hline 7 & 5.577 & 5.576 & 5.575 \\
\hline 8 & 5.602 & 5.602 & 5.601 \\
\hline 9 & 5.616 & 5.616 & 5.615 \\
\hline 10 & 5.626 & 5.626 & 5.626 \\
\hline 11 & 5.634 & 5.630 & 5.634 \\
\hline 12 & 5.640 & 5.640 & 5.640 \\
\hline 13 & 5.646 & 5.646 & 5.646 \\
\hline 14 & 5.651 & 5.652 & 5.652 \\
\hline 15 & 5.656 & 5.656 & 5.657 \\
\hline 16 & 5.660 & 5.661 & 5.661 \\
\hline 17 & 5.664 & 5.665 & 5.665 \\
\hline 18 & 5.668 & 5.669 & 5.669 \\
\hline 19 & 5.671 & 5.672 & 5.673 \\
\hline 20 & 5.674 & 5.676 & 5.677 \\
\hline
\end{tabular}

Table 2. Comparison table for three levels of charging currents for different values of solar panel voltage

Simulation data of the three levels of charging currents when the solar panel voltage is varied

\begin{tabular}{|c|c|c|c|}
\multicolumn{5}{|c|}{$\begin{array}{c}\text { Sol } \\
\text { ar Panel } \\
\text { Vin (V) }\end{array}$} & $\begin{array}{l}\text { Icharge(Min) } \\
\text { in mA when } \\
\text { Rshunt }=6 \Omega\end{array}$ & $\begin{array}{l}\text { Icharge(Mid) in } \\
\text { mA when } \\
\text { Rshunt }=4.5 \Omega\end{array}$ & $\begin{array}{l}\text { Icharge(Max) } \\
\text { in mA when } \\
\text { Rshunt }=3 \Omega\end{array}$ \\
\hline 6 & 037.636 & 045.602 & 058.880 \\
\hline 7 & 082.101 & 105.845 & 150.318 \\
\hline 8 & 087.076 & 112.554 & 160.541 \\
\hline 9 & 090.271 & 116.863 & 167.122 \\
\hline 10 & 092.788 & 120.261 & 172.330 \\
\hline 11 & 094.919 & 123.147 & 176.761 \\
\hline 12 & 096.795 & 125.688 & 180.672 \\
\hline 13 & 098.483 & 127.98 & 184.203 \\
\hline 14 & 100.025 & 130.076 & 187.417 \\
\hline 15 & 101.446 & 132.013 & 190.431 \\
\hline 16 & 102.766 & 133.818 & 193.227 \\
\hline 17 & 103.999 & 135.509 & 195.853 \\
\hline 18 & 105.153 & 137.101 & 198.332 \\
\hline 19 & 106.240 & 138.604 & 200.682 \\
\hline 20 & 107.262 & 140.026 & 202.915 \\
\hline
\end{tabular}

The data in Table 2 are presented in plot form in Fig. 3 and it shows the trends of the changes in the charging currents for different values of the solar panel voltage.

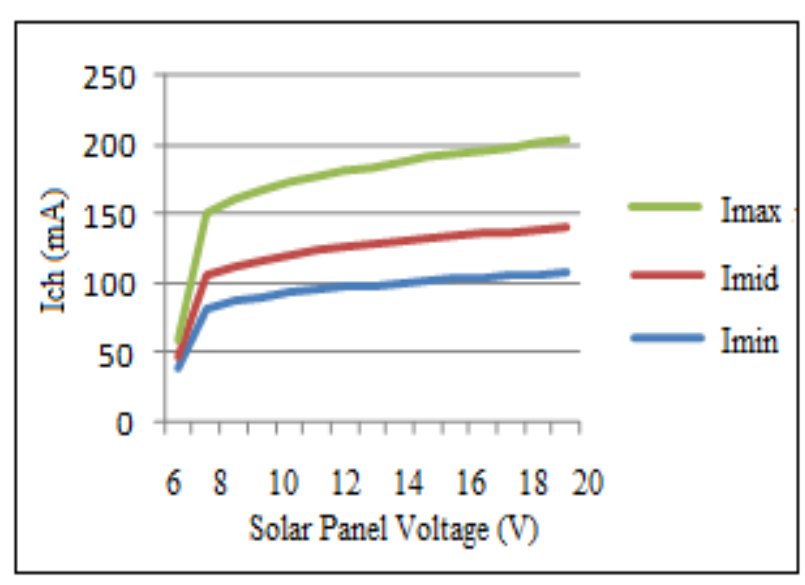

Fig.3.: Charging Currents (mA) of mobile battery for different values of solar panel voltages.

\section{Experimental Work and Results}

Obviously, the presented electronic circuit is a current limit charging circuit and it involves working with the solar module with specifications as shown in Fig. 4.

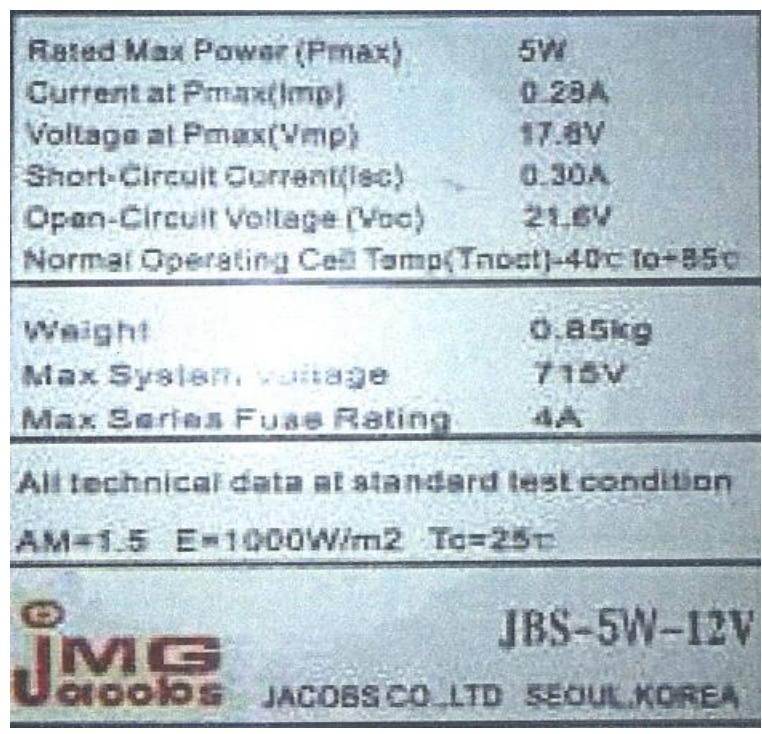

Fig. 4: Front view of tested solar panel with its specifications

The objective of the first experiment or practical testing is to find out the voltage levels that come out directly from the solar panel itself and to confirm the test results with the specifications given by the manufacturer. The type of solar panel module is JBS-5W-12V. This panel has Rated Max. Power $(\operatorname{Pmax}=5 \mathrm{~W})$, Current at Pmax $(\operatorname{Imp}=0.28 \mathrm{~A})$, Voltage at Pmax $(\mathrm{Vmp}=17.6 \mathrm{~V})$, Short - Circuit Current $(\mathrm{Isc}=0.3 \mathrm{~A})$, Open - Circuit Voltage $(\mathrm{Voc}=21.6 \mathrm{~V})$. The materials needed to do this experiment are: Voltmeter, Solar Module / JBS-5W$12 \mathrm{~V}$, and wiring. Based on the theory of photovoltaic, the short circuit current and the open circuit voltage can be measured under certain lighting conditions that indicate the two ends of the I-V curve of the solar panel with appropriate testing load $[11,12]$. The solar panel works at different operating points along the I-V curve of the PV. The practical measurements were taken after putting the solar panel in flat surface, in an area that has no shadow obstructions from the surroundings such as tall buildings. The output voltage of the solar module was measured every half an hour starting from the 9:00 AM till sunset. Table 3 explains the related readings. 
Table 3: Open Circuit Output Voltages Day Timing of the Solar Panel Module / JBS-5W-12V

\begin{tabular}{|c|c|c|}
\hline Time & $\begin{array}{l}\text { Output Voltage } \\
\text { (V) }\end{array}$ & $\begin{array}{l}\text { Weather } \\
\text { Notes }\end{array}$ \\
\hline 09:00 & 20.71 & \\
\hline $09: 30$ & 20.51 & \\
\hline $10: 00$ & 20.10 & \\
\hline $10: 30$ & 19.20 & \\
\hline 11:00 & 20.10 & \\
\hline $11: 30$ & 20.03 & \\
\hline $12: 00$ & 19.80 & \\
\hline $12: 30$ & 19.57 & \\
\hline $13: 00$ & 19.11 & \\
\hline $13: 30$ & 18.48 & \\
\hline $14: 00$ & 18.78 & \\
\hline $14: 30$ & 18.57 & \\
\hline $15: 00$ & 18.79 & \\
\hline $15: 30$ & 18.93 & \\
\hline $16: 00$ & 18.48 & Cloudy \\
\hline $16: 30$ & 18.25 & Thick Cloud \\
\hline $17: 00$ & 18.55 & Bright \\
\hline $17: 30$ & 17.83 & \\
\hline $18: 00$ & 17.10 & \\
\hline $18: 30$ & 14.91 & Close to Sunset \\
\hline $19: 00$ & 2.14 & After Sunset \\
\hline
\end{tabular}

Fig. 5 shows the data of Table 3 and both the figure and the data presented in the table explain the availability of the output voltages with biggest values during midday timing.

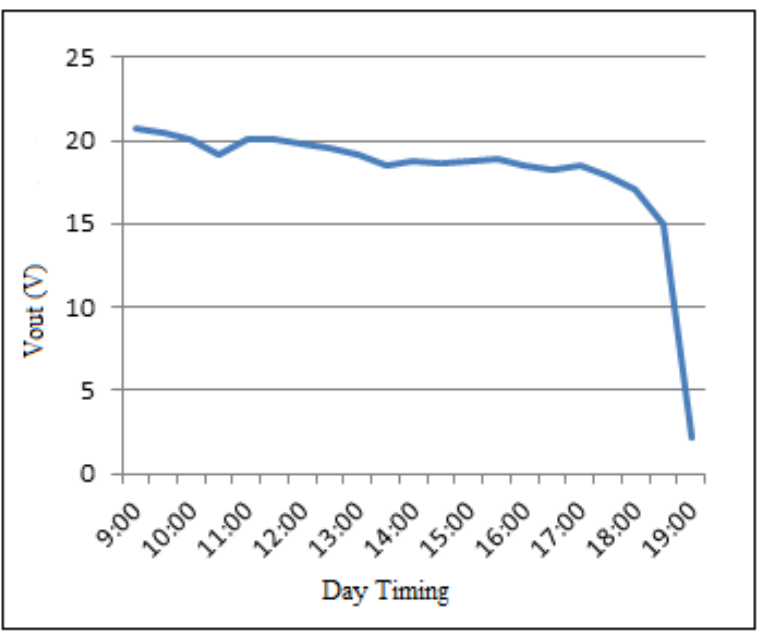

Fig. 5: Open Circuit Output Voltages Day Timing of the Solar Panel Module / JBS-5W-12V

In the second experiment, a load resistor $(\mathrm{RL}=100 \Omega /$ $10 \mathrm{~W}$ ) was connected at the output of the solar module as a continuous load during day timing and the load currents and voltages readings were collected by meters at each half hour. Table 4 shows all related data when the load was connected to the solar module.
Table 4: Vout (V), I_Load (A), and Transferred Power (W) from Solar Panel

\begin{tabular}{|c|c|c|c|}
\hline Time & $\begin{array}{l}\text { Output } \\
\text { Voltage } \\
(\mathrm{V})\end{array}$ & $\begin{array}{l}\text { Load current } \\
\text { (I_Load) }(\mathrm{A})\end{array}$ & $\begin{array}{l}\text { Transfer } \\
\text { Power }(\mathrm{W})\end{array}$ \\
\hline $09: 00$ & 20.49 & 0.27 & 5.53 \\
\hline $09: 30$ & 20.47 & 0.27 & 5.53 \\
\hline $10: 00$ & 20.46 & 0.27 & 5.52 \\
\hline $10: 30$ & 20.01 & 0.26 & 5.20 \\
\hline $11: 00$ & 18.33 & 0.24 & 4.40 \\
\hline $11: 30$ & 18.45 & 0.25 & 4.61 \\
\hline $12: 00$ & 18.47 & 0.25 & 4.62 \\
\hline $12: 30$ & 18.37 & 0.25 & 4.59 \\
\hline $13: 0$ & 18.35 & 0.25 & 4.59 \\
\hline $13: 30$ & 17.98 & 0.23 & 4.14 \\
\hline $14: 00$ & 18.07 & 0.22 & 3.98 \\
\hline $14: 30$ & 17.81 & 0.21 & 3.74 \\
\hline $15: 00$ & 16.80 & 0.16 & 2.69 \\
\hline $15: 30$ & 16.29 & 0.16 & 2.61 \\
\hline $16: 00$ & 12.60 & 0.12 & 1.51 \\
\hline $16: 30$ & 13.01 & 0.12 & 1.56 \\
\hline $17: 00$ & 8.14 & 0.07 & 0.57 \\
\hline $17: 30$ & 5.02 & 0.04 & 0.20 \\
\hline $18: 00$ & 2.14 & 0.01 & 0.02 \\
\hline $18: 30$ & 0.50 & 0.00 & 0.00 \\
\hline & & & \\
\hline
\end{tabular}

Fig. 6 shows the data of Table 4 and the figure explains the output voltages, load currents and then the values of transferred power during day timing.

The third experiment was building the presented circuit explained in Fig. 2 including five multimeters for measurements. First meter measures the supply voltage with range of voltages from $4 \mathrm{~V}$ up to $20 \mathrm{~V}$, second meter measures the voltage across zener diode, third meter measures the voltage across the real mobile battery which was connected and charged by the presented circuit, forth meter measures a charging current of the mobile battery and the fifth meter measures the voltage across shunt resistor. All readings were taken for three cases: firstly shunt resistor equal $6.3 \Omega$ to have minimum charging current, secondly when shunt resistor equals to $4.5 \Omega$ to have medium value of charging current, and finally when shunt resistor equals $3.4 \Omega$ for bigger value of charging current. 


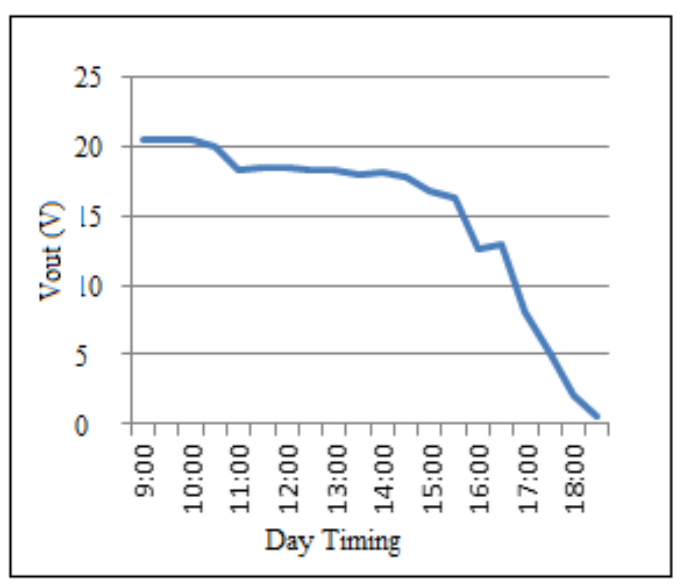

(a)

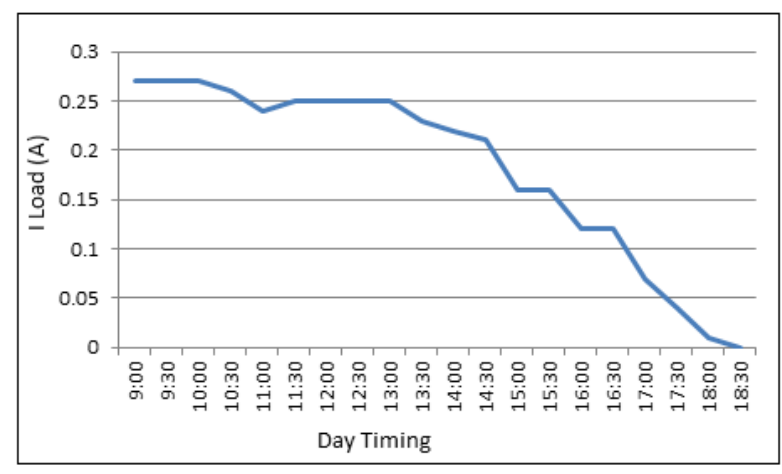

(b)

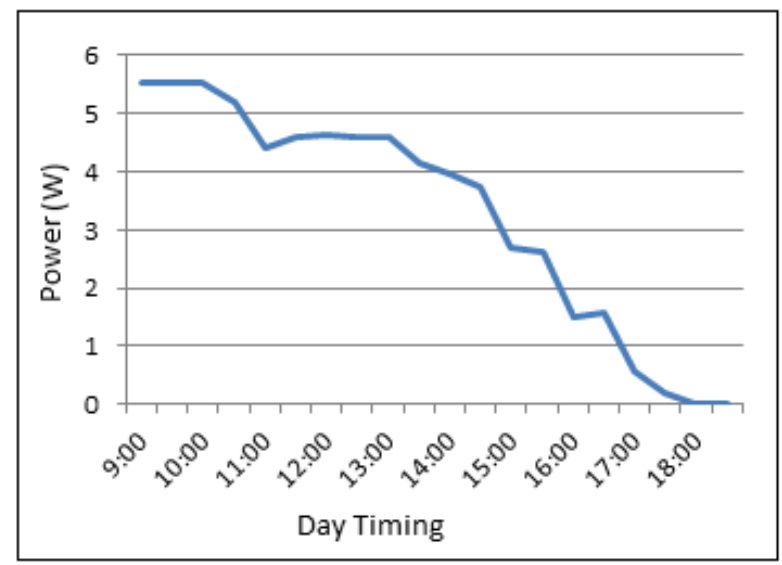

(c)

Fig. 6. (a) Vout (V), (b) I load (A), and (c) Transferred Power (W) from Solar Panel versus day timing

The following three tables: Table 5, Table 6 and Table 7 represent the practical measured results obtained for the different levels of charging currents with the supply voltage varying from $4 \mathrm{~V}$ to $20 \mathrm{~V}$.
Table 5: Practical readings for minimum charging current at shunt resistor equal to $6.3 \Omega$

\begin{tabular}{|c|c|c|c|c|}
\hline \multicolumn{5}{|c|}{$\begin{array}{l}\text { Practical readings of test points in the proposed portable } \\
\text { solar charger at shunt Resistor }=6.3 \Omega\end{array}$} \\
\hline $\begin{array}{l}\text { Solar } \\
\text { Panel } \\
\text { Vin } \\
\text { (V) }\end{array}$ & $\begin{array}{l}\text { Zener } \\
\text { Voltage } \\
\text { Vz }(\mathrm{V})\end{array}$ & $\begin{array}{l}\text { Mob. } \\
\text { Bat.Voltage } \\
\text { (V) }\end{array}$ & $\begin{array}{l}\text { Charge } \\
\text { Current I } \\
\text { Mob. } \\
\text { Battery } \\
(\mathrm{mA})\end{array}$ & $\begin{array}{l}\text { Shunt } \\
\text { Res. } \\
\text { Voltage } \\
(\mathrm{mV})\end{array}$ \\
\hline 4 & 3.234 & 1.610 & 049.27 & 310.0 \\
\hline 5 & 4.202 & 2.382 & 072.72 & 457.4 \\
\hline 6 & 5.083 & 3.089 & 094.30 & 593.7 \\
\hline 7 & 5.386 & 3.337 & 101.93 & 642.0 \\
\hline 8 & 5.467 & 3.412 & 104.25 & 656.7 \\
\hline 9 & 5.437 & 3.416 & 104.56 & 661.0 \\
\hline 10 & 5.697 & 3.527 & 107.80 & 678.2 \\
\hline 11 & 5.710 & 3.545 & 108.30 & 681.6 \\
\hline 12 & 5.717 & 3.561 & 108.74 & 684.3 \\
\hline 13 & 5.721 & 3.573 & 109.10 & 686.6 \\
\hline 14 & 5.722 & 3.583 & 109.36 & 688.0 \\
\hline 15 & 5.720 & 3.588 & 109.55 & 689.3 \\
\hline 16 & 5.719 & 3.588 & 109.45 & 688.4 \\
\hline 17 & 5.695 & 3.584 & 109.34 & 687.7 \\
\hline 18 & 5.678 & 3.581 & 109.22 & 686.0 \\
\hline 19 & 5.655 & 3.575 & 109.96 & 685.1 \\
\hline 20 & 5.632 & 3.563 & 108.70 & 683.0 \\
\hline
\end{tabular}

Table 6: Practical readings for medium charging current at shunt resistor equal $4.5 \Omega$

Practical readings of test points in the proposed portable solar charger at shunt Resistor $=4.5 \Omega$

\begin{tabular}{|l|l|l|l|l|}
\hline $\begin{array}{l}\text { Solar } \\
\text { Panel } \\
\text { Vin } \\
(\mathrm{V})\end{array}$ & $\begin{array}{l}\text { Zener } \\
\text { Voltage } \\
\text { Vz (V) }\end{array}$ & $\begin{array}{l}\text { Mob. Bat. } \\
\text { Voltage } \\
(\mathrm{V})\end{array}$ & $\begin{array}{l}\text { Charge } \\
\text { Current I I } \\
\text { Mob. } \\
\text { Battery } \\
(\mathrm{mA})\end{array}$ & $\begin{array}{l}\text { Shunt } \\
\text { Res. } \\
\text { Voltage } \\
(\mathrm{mV})\end{array}$ \\
\hline 4 & 3.214 & 1.632 & 049.88 & 226.2 \\
\hline 5 & 4.228 & 2.469 & 075.38 & 341.9 \\
\hline 6 & 5.149 & 3.227 & 098.64 & 447.5 \\
\hline 7 & 5.640 & 3.637 & 111.10 & 504.2 \\
\hline 8 & 5.711 & 3.699 & 113.00 & 512.9 \\
\hline 9 & 5.743 & 3.73 & 113.92 & 517.2 \\
\hline 10 & 5.767 & 3.756 & 114.70 & 520.7 \\
\hline 11 & 5.787 & 3.778 & 115.37 & 523.9 \\
\hline 12 & 5.804 & 3.799 & 116.02 & 526.8 \\
\hline 13 & 5.818 & 3.817 & 116.52 & 529.1 \\
\hline 14 & 5.832 & 3.836 & 117.11 & 531.7 \\
\hline 15 & 5.844 & 3.855 & 117.62 & 534.2 \\
\hline 16 & 5.856 & 3.872 & 118.18 & 536.8 \\
\hline 17 & 5.869 & 3.892 & 118.78 & 539.5 \\
\hline 18 & 5.880 & 3.910 & 119.40 & 542.3 \\
\hline 19 & 5.890 & 3.932 & 120.00 & 545.0 \\
\hline 20 & 5.900 & 3.950 & 120.50 & 547.4 \\
\hline & & & & \\
\hline
\end{tabular}


Table 7: Practical readings for maximum charging current at shunt resistor equal $3.4 \Omega$

Practical readings of test points in the proposed portable solar charger at shunt Resistor $=3.4 \Omega$

\begin{tabular}{|l|l|l|l|l|}
\hline $\begin{array}{l}\text { Solar } \\
\text { Panel } \\
\text { Vin (V) }\end{array}$ & $\begin{array}{l}\text { Zener } \\
\text { Voltage } \\
\text { Vz (V) }\end{array}$ & $\begin{array}{l}\text { Mob. } \\
\text { Bat. } \\
\text { Voltage } \\
(\mathrm{V})\end{array}$ & $\begin{array}{l}\text { Charge } \\
\text { Current } \\
\text { Mob. } \\
\text { Battery } \\
(\mathrm{mA})\end{array}$ & $\begin{array}{l}\text { Shunt } \\
\text { Res. } \\
\text { Voltage } \\
(\mathrm{mV})\end{array}$ \\
\hline 4 & 3.220 & 1.700 & 051.84 & 171.6 \\
\hline 5 & 4.270 & 2.590 & 079.15 & 264.2 \\
\hline 6 & 5.230 & 3.407 & 104.05 & 354.4 \\
\hline 7 & 5.640 & 3.766 & 114.98 & 384.9 \\
\hline 8 & 5.710 & 3.820 & 116.79 & 390.9 \\
\hline 9 & 5.746 & 3.860 & 117.83 & 394.0 \\
\hline 10 & 5.770 & 3.886 & 118.61 & 396.4 \\
\hline 11 & 5.79 & 3.908 & 119.32 & 398.2 \\
\hline 12 & 5.806 & 3.929 & 119.94 & 399.9 \\
\hline 13 & 5.821 & 3.951 & 120.6 & 401.6 \\
\hline 14 & 5.833 & 3.969 & 121.15 & 403.1 \\
\hline 15 & 5.847 & 3.988 & 121.74 & 404.7 \\
\hline 16 & 5.858 & 4.007 & 122.3 & 406.5 \\
\hline 17 & 5.870 & 4.028 & 122.93 & 408.3 \\
\hline 18 & 5.881 & 4.046 & 123.48 & 409.6 \\
\hline 19 & 5.892 & 4.065 & 124.07 & 411.2 \\
\hline 20 & 5.902 & 4.087 & 124.76 & 413.0 \\
\hline & & & & \\
\hline
\end{tabular}

The practical readings of Table 5, Table 6 and Table 7 were presented in a plot form in Fig. 7. It represents the practical trends of the zener diode voltage when the solar panel voltage is varying from $4 \mathrm{~V}$ to $20 \mathrm{~V}$ for the three levels of charging currents. Fig 8 represents the trends of charging currents in different charging levels for shunt resistor values $6.3 \Omega$ for minimum, $4.5 \Omega$ for medium, and $3.4 \Omega$ for maximum level charging currents.

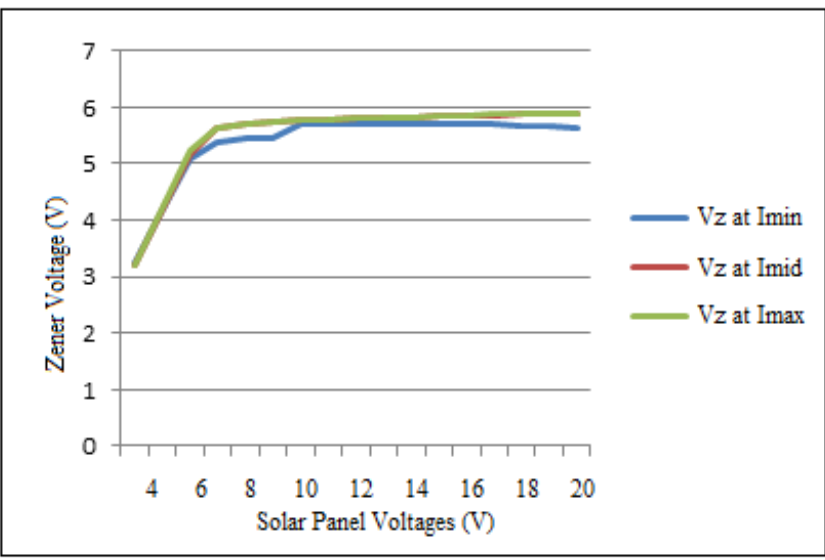

Fig. 7: Practical Readings of Zener Voltages Trends

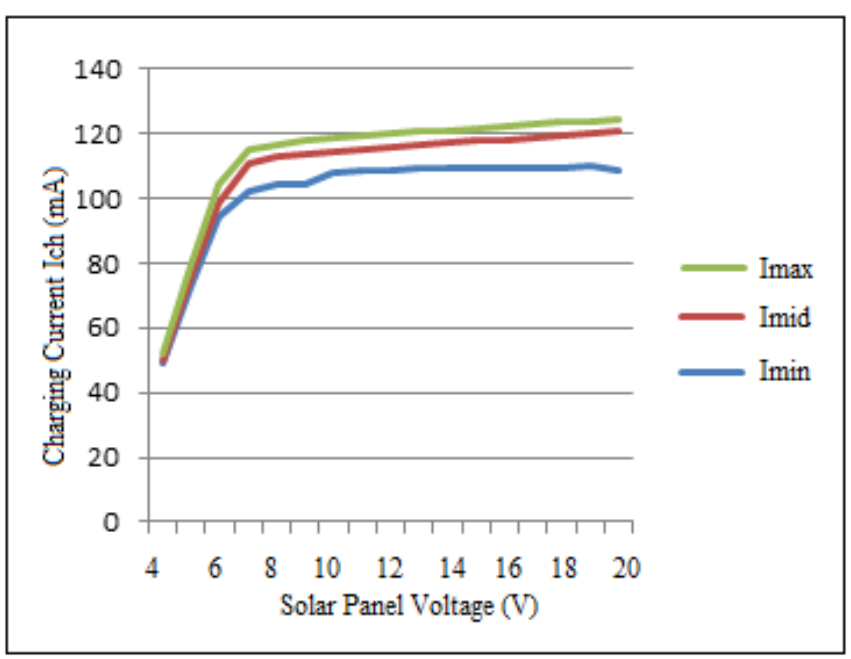

Fig. 8: Practical Readings of Charging Currents Trends

\section{Conclusions}

This paper proposes an electronic design that can be used for mobile device charging purposes. The following remarks could be the summary of the findings from this work.

- Solar energy could be effectively used as an alternative source of power for charging mobile devices at any location especially in places where sun light or an equivalent light source is easily available. For maximum absorption of solar power, the direction of the panel should be direct line-ofsight or perpendicular with sun light.

- There is an agreement between the practical readings and the simulation data showing that the Multisim Program is quite suitable and powerful for the electronic design simulations.

- One of the important objectives of the design is regulation of the battery charging current and this is achieved through selective choice of the shunt resistor. This controlling function is verified through the simulated data and the practical measurements when the battery of mobile device was empty and hence taking more charging current and then the charging current was limited to a certain required level depending on the values of the shunt resistor. The case of minimum charging current was clearly shown in practical records for shunt resistor value of $6.3 \Omega$ and we noted that the charging current was limited at approximately fixed level equal to 109 $\mathrm{mA}$.

- The proposed electronic design is simple to practically implement with low cost electronic components and selection of suitable components (zener diodes, Darlington transistors, etc..) is important to achieve the desired voltage and charging current levels. 


\section{References}

[1] Qutaiba I. Ali, "Design and Implementation of Mobile Phone Charg Harvesting," Iraq J. of Electrical and Electronic Engineering, Vol. 7 No.1 2011, pp69-72.

[2] High efficiency solar battery charger with embedded MPPT, July 2012 Doc ID 18080 Rev 4, (C) 2012 STMicroelectronics: http://www.st.com.

[3] How to make a solar iPod/iPhone charger -aka MightyMintyBoost by Honus on May 2, 2009. http://www.instructables.com/id/How-to-make-a-solariPodiPhone-charger-aka-Might/.

[4] Colin Mitchell. "5v Solar Power Supply" 2005. Talking Electronics. $19 \quad$ Feb.2012. http://talkingelectronics.com/projects/Solarlight/PowerSu pply5vSolar.html/

[5] G. Forest Cook, Shunt mode Solar Charger Controller Circuit, March 2010. http://www.solorb.com/elect/solarcirc/shuntreg1/index.html

[6] NI MutltSIM, http://www.ni.com/multisim/
[7] Paul A. Lynn, Electricity from Sunlight: An Introduction to Photovoltaics, Wiley; 1 edition, May 17, 2010.

[8] John Twidell, Tony Weir, Renewable Energy Resources, $2^{\text {nd }}$ Edition, Taylor \&Francis, 2006.

[9] J. Yoon, A.J. Baca, S.-I. Park, P. Elvikis, J.B. Geddes, L. Li, R.H. Kim, J. Xiao, S. Wang, T.H.Kim, M.J. Motala, B.Y. Ahn, E.B. Duoss, J.A. , Lewis, R.G. Nuzzo, P.M. Ferreira, Y. Huang, A.Rockett and J.A. Rogers, "Ultrathin Silicon Solar Microcells for Semitransparent, Mechanically Flexible and Microconcentrator Module Designs," Nature Materials 7, 907-915 (2008).

[10] J. P. Hare, IOP press, Demonstrating the wonderful amplifying action of a transistor, Journal of Physics Education, March 2004, p.128-131

[11] H. A. Attia, H. W. Ping, Y. Al-Mashhadany, "Design and analysis for high performance synchronized inverter with PWM power control" 2013 IEEE Conference on Clean Energy and Technology (CEAT 2013), Lankgkawi, Malaysia.

[12] Wenyan Jia ; Quan Tao ; Mingui Sun, "Solar Cell Phone Charger Performance in Indoor Environment," IEEE 37th Annual Northeast Bioengineering Conference (NEBEC), 2011. 